\title{
E-COMMERCE AND COMPETENCE, IMPACT ON BUSINESS PERFORMANCE: EMPIRICAL STUDY ON IMPLEMENTATION E-COMMERCE BY STUDENTS AT PASUNDAN UNIVERSITY
}

\author{
Oleh: \\ Muhammad Ilham \\ Ina Ratnamiasih \\ Departement of Management, Pasundan University, Bandung, Indonesia
}

\begin{abstract}
This research was conducted to determine the influence of e-commerce implementation and student competence on the success of business performance. The rapid growth of Small Business Enterprise (SME) throughout the Asian economy, especially in Indonesia is partly due to the rapidly developing information technology. The internet has become an important business tool, to the point where even SME utilize e-commerce. SMEs in Indonesia are proven to be the most dynamic and vibrant sector. The use of e-commerce is increasingly widespreading among young people and teenagers. Students-especially college students-are becoming more interested in doing entrepreneurship in between their classes. The research method used was the quantitative method with the help of analytical tools, namely multiple regression and correlation. The results showed that e-commerce and competence have a great influence on the success of businesses run by students.
\end{abstract}

Keywords: E-Commerce, Competence, Business Performance, Students

\section{INTRODUCTION}

The development of business today has been so rapid, that it provides great opportunities for community initiative and creativity. Through better internet technology, economic globalization, environmental complexity and rapid competitive growth are issues that occur in all parts of the world. Even now the internet is not only being used for finding information, communication and entertainment, but also as a means for doing business (e-commerce). Kareem (2014) said that e-commerce adoption has a significant impact on service speed, reduction in operating costs and profitability. This makes online business in Indonesia more attractive to all parties, both educated and not, both young people and the older generation. According to Rahayu and Day (2015) the use of e-commerce makes it easy to find information, transactions, and many other aspects of business. In the initial stage (Kapurubandara, and Lawson, 2008), 24hour service time, communication with consumers, payment transactions and receipt of goods are the benefits offered in running e-commerce (Lesmono, 2015; Rahayu \& Day, 2015). 
Online stores will continue to grow along with technological advancements, and the character of buyers is also changing because of the convenience offered by the internet. Based on data from Internet World Stats, Indonesia is ranked in the top 5 in terms of numbers of internet users. Previously, Indonesia was ranked 6th in internet usage. Internet World Stats itself released the latest data for the largest netizen population in March 2019. There are Brazil, the United States, India and China which are at the top position, above Indonesia. However, the number of internet users in Indonesia is not yet supported with good access and speeds. According to the survey by the Indonesian Internet Service Providers Association (APJII) in collaboration with the Indonesian poll study (May 16, 2019), the number of internet users in Indonesia grew by $10.12 \%$. This survey involved 5,900 samples with a margin of error of $1.28 \%$. This field data was taken during the period from March to April 14, 2019. The results of a total population of 264 million people in Indonesia, there were 171.17 million people or around $64.8 \%$ of internet users. The data increased from 2017 which was recorded as much as $54.86 \%$.

The Indonesian Internet Service Providers Association (APJII) identifies the use of the internet in terms of the economy, public services, education, lifestyle, sociopolitics, to health. The following is the percentage of access made by internet users in Indonesia in 2018 based on 6 sectors, as in Table 1. below:

Table 1. Interest Usage Based on 6 Sectors (2018)

\begin{tabular}{|c|c|c|c|}
\hline No & Economic Sector & No & Public Services Sector \\
\hline 1 & Search prices $(45,14 \%)$ & 1 & Legal information $(16,17 \%)$ \\
\hline 2 & Help with work $(41,04)$ & 2 & Administrative information $(12,51 \%)$ \\
\hline 3 & Buy information $(37,82 \%)$ & 3 & Registration of KTP / SIM / Passport (11,78\%) \\
\hline 4 & Online shopping $(32,19 \%)$ & 4 & Reporting Taxes $(11,12 \%)$ \\
\hline 5 & Find work $(26,19 \%)$ & 5 & Report complaints $(9,58 \%)$ \\
\hline 6 & Banking transactions $(17,04 \%)$ & & \\
\hline 7 & Selling online $(16,98 \%)$ & & \\
\hline No. & Education Sector & & Lifestyle Sector \\
\hline 1 & Social media $(87,13 \%)$ & 1 & Read articles $(55,30 \%)$ \\
\hline 2 & Download music $(71,10 \%)$ & 2 & Watch tutorial videos $(49,67 \%)$ \\
\hline 3 & Watch movies $(70,23 \%)$ & 3 & Share articles $(21,73)$ \\
\hline 4 & Entertainment / hobby news $(58,01 \%)$ & 4 & Online courses $(17,85 \%)$ \\
\hline 5 & Read news $(57,13 \%)$ & 5 & List of schools $(14,63 \%)$ \\
\hline 6 & Play games $(54,13 \%)$ & & \\
\hline 7 & Sports news $(50,48 \%)$ & & \\
\hline No. & Social-Political Sector & & Health Sector \\
\hline 1 & Social / environmental news $(50,26 \%)$ & 1 & Search health information $(51,06 \%)$ \\
\hline 2 & Religious information $(41,55 \%)$ & 2 & Health consultation $(14,05 \%)$ \\
\hline 3 & Political news $(36,94 \%)$ & & \\
\hline 4 & Charity $(16,31)$ & & \\
\hline
\end{tabular}


The results of the study have proven that entrepreneurship is an important component of local economic development. Therefore, fostering entrepreneurship through increased use of e-commerce in micro, small and medium enterprises (SME) is an important goal for policy makers and governments almost all over the world (Adamek, 2007). Based on the results of the APJII survey, online business has a great potential to continue to grow. Table 1 shows the number of internet access for online sales of $16.98 \%$. This can be seen from the increasing interest in online business, not only in the working community, but also in students. The use of the internet is increasingly popular among the younger generation, especially students in Indonesia. Although still very far behind compared to the use of e-commerce in large companies, but with the current economic conditions that are increasingly unstable, the role of SMEs is increasingly important in online market competition (Rahayu \& Day, 2015). The results of many studies have proven that e-commerce has significantly increased business profits (Yulimar, 2014)

In addition to the government, one of the institutions that is expected to encourage the development of SMEs is universities. As an institution that prepares prospective economic actors, the university is responsible for assisting the government in promoting entrepreneurship in students, so that the unemployment rate will not increase (Han and Jin, 2009). Some universities have paid special attention to entrepreneurship. This is evident from the curriculums that are clearly paying attention to entrepreneurship (Ratnamiasih \& Indra Setia, 2016), which Pasundan University has done.

The phenomenon of online business is a trend in Pasundan University students. But as with most e-commerce in developing countries, the development of online business by students is often difficult. Most of the students complained about obstacles that resulting no increase in sales, or even sales target not fulfilled. Problems felt by consumers include the lack of initiative in running an online business, the service and quality of the products provided are less than satisfactory, and responsibility is lacking. This is related to the readiness to become a good entrepreneur. To find out how far students use e-commerce in conducting their business, a pre-survey of 30 students who become entrepreneurs of the Faculty of Economics, Social Sciences, and Faculty of Engineering was conducted. The biggest percentage of students using internet media are Instagram with $90 \%$, whatsapp with $60 \%$, Line with $56.7 \%$, while Facebook with a percentage of $40 \%$, the rest use other social media by $10 \%$. The preference does not indicate the large market potential, but 
mainly due to the habits of students as users of the application. Based on the pre-survey, it can also be seen that students have not maximized the use of e-commerce, even though the complexity of transactions carried out in their business is rather high / diverse.

The competency factor is another source of the causes of businesses run by students to be less successful. Student competency in using e-commerce is still not good, especially their knowledge and expertise in using e-commerce. Even though the ability to use e-commerce is very important to produce success in business (Maryeni, et.al, 2014; Sethela, 2014; Yulimar, 2014). Based on these descriptions, this study was conducted to determine the effect of E-commerce Implementation and competence on the performance of Online-Based Enterprises conducted by Students at Pasundan University.

\section{CONCEPTUAL FRAMEWORK}

E-commerce is the spread of purchases, sales, marketing of goods and services through electronic systems such as the internet, television, or other computer networks. E-commerce is a part of ebusiness where the scope of e-business is broader, not only in commerce but also includes collaborating with business partners, customer service, job vacancies and others. (Kapurubandara, and Lawson, 2008; Maryeni, et.al, 2014). The emergence of buying and selling online causes various products to be seen and known prices and even negotiate prices without having to come directly to where the goods are sold. E-commerce provides benefits for businesses in increasing efficiency, reducing inventory costs, increasing sales, increasing customer relationships, penetrating new markets, and ultimately financial returns. (Han and Jin, 2009).

E-commerce has a positive effect on the performance of SME companies (Mendo, and Fitzgerald, 2005). Another study conducted by Kareem (2014) in his research said that e-commerce adoption has a significant impact on service operations, reduced operating costs and profitability and more effective e-commerce to further improve performance. Beside implementation of e-commerce, competence affects the performance of business people. The higher the competency, the better the performance will be (Rahayu and Day, 2017). Respondents in this study were 150 SME entrepreneurs in Surabaya. The importance of competence in running e-commerce has been recognized in today's digital era. Chong and Pervan (2009) believe that although web-based sales strategies do not guarantee success, small companies that have built web sites are aware of the many benefits, including 
opportunities to increase revenue, ability to expand reach to global markets, the ability to stay open 24 hours a day, seven days a week, the ability to see new business opportunities and to take advantage of them, etc. In view of this discussion, we formulate two key hypotheses:
- E-commerce implementation effects on Performance

- Human resources competence effects on performance

The relationship between ecommerce implementation and student competence on business performance can be seen in the following research framework.

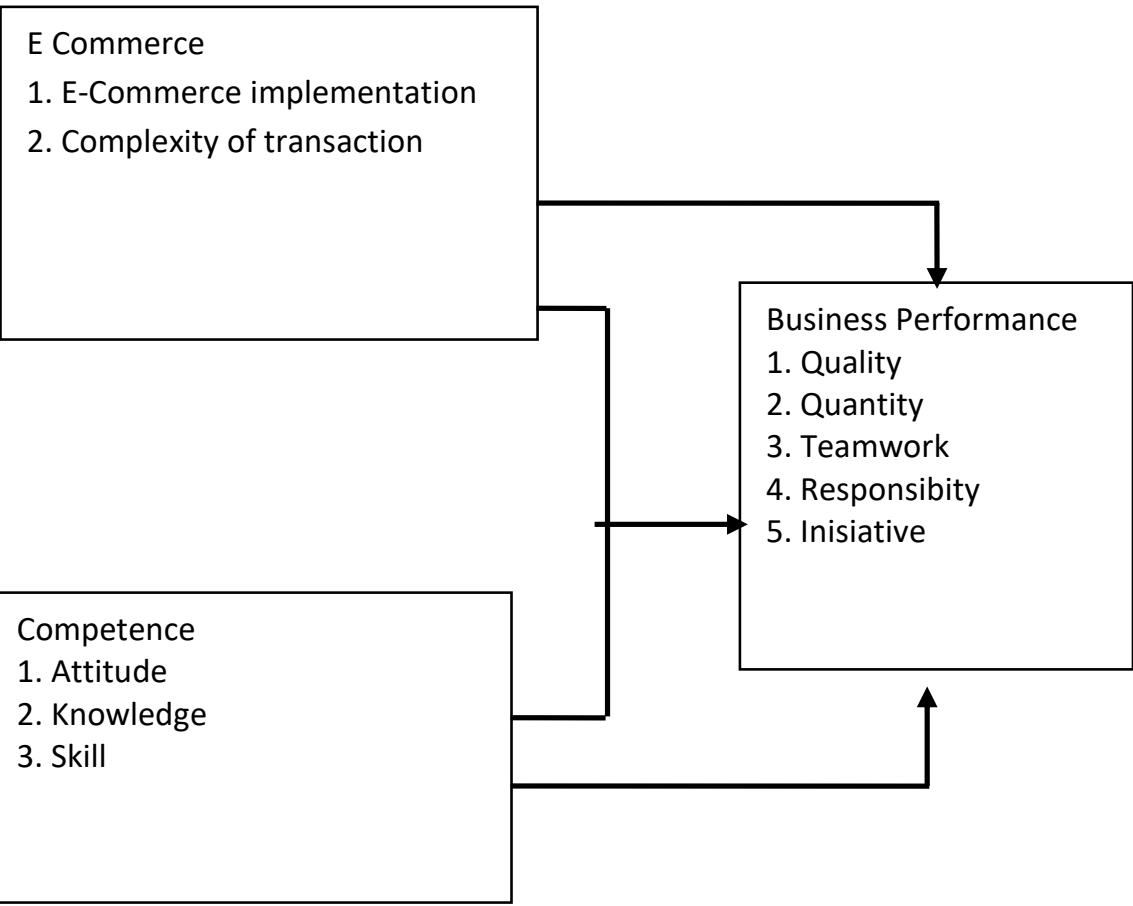

Picture 1. Research Framework

\section{METHODS AND DATA}

The method used in this research is quantitative research (Sekaran, 1992). The population in this study were students at Pasundan University located in Bandung, West Java Province, Indonesia. Students who are a special population of the class of 2017 (semester 4) because it is assumed that at that time students have passed the adaptation period but still have not made a final project. In that semester the curriculum has also provided provisions as an introduction and encouragement in entrepreneurship. The number of Faculties studied were at the Faculty of Economics and Business (751 people), the Faculty of Social and Political Sciences (1,143 people), and the Faculty of Engineering (570 people). Population of students that do entrepreneur 
are $10 \%$ of total student from the faculties mentioned above, which is 247 students. Samples were taken proportionally in each faculty with a total of 100 respondents. To test the validity of the data, two types of testing are needed, namely the rest of validity test and the test of reliability with the results as shown in the Table 2. and 3. below:

Table 2. Test Results of Variable Validity of E-Commerce Implementation

\section{E-commerce Competence Business Performance}

\begin{tabular}{cccccc}
\hline Item & $\mathbf{r}_{\mathbf{x y}}$ & Item & $\mathbf{r}_{\mathbf{x y}}$ & Item & $\mathbf{r}_{\mathbf{x y}}$ \\
\hline 1 & 0.438 & 1 & 0.468 & 1 & 0.355 \\
2 & 0.323 & 2 & 0.352 & 2 & 0.307 \\
3 & 0.355 & 3 & 0.354 & 3 & 0.397 \\
4 & 0.329 & 4 & 0.333 & 4 & 0.373 \\
5 & 0.417 & 5 & 0.482 & 5 & 0.360 \\
6 & 0.367 & 6 & 0.604 & 6 & 0.434 \\
7 & 0.421 & 7 & 0.514 & 7 & 0.579 \\
8 & 0.470 & 8 & 0.535 & 8 & 0.482 \\
9 & 0.340 & 9 & 0.416 & 9 & 0.328 \\
\hline
\end{tabular}

Table 3. Test Results of Reliability

\begin{tabular}{cc} 
Variabel & Cronbach's Alpha \\
\hline Implementasi E-commerce & 0.711 \\
Kompetensi & 0.769 \\
Kinerja & 0.725 \\
\hline
\end{tabular}

After testing, all items of statements regarding e-commerce variables, competencies and business performance are said to be valid because they have a value greater than 0.3. Reliability testing is performed on three variables using the Cronbanch's-Alpa method, with the results above 0.7 , which means that all variables can be said to be reliable. Before testing the hypothesis through the T test and the F test, some of the classic assumptions used like autoclastic heteroscedasticity and mullticolinierity is tested on.(Sekaran, 1992).

\section{RESULTS}

Based on the results of the survey through the questionnaire then based on the cumulative achievement index (GPA), students who have their GPA above average ie GPA above 3 are $63 \%$, while the rest are below average (39\%). Based on the 
characteristics of the internet media used to run e-commerce can be seen in the Table 4 .

below:

Table 4. Number of Respondents Based on Internet Media used

\begin{tabular}{cccc} 
No. & Media & Frequency & Percentage \\
\hline 1. & Instagram, Facebook & 27 & $27 \%$ \\
2. & Instagram, Whatsapp, Facebook & 16 & $16 \%$ \\
3. & Instagram, Facebook, Line & 37 & $37 \%$ \\
4. & Instagram, Line & 10 & $10 \%$ \\
5. & Instagram, Whatsapp, Line & 10 & $10 \%$ \\
\hline & Total & 100 & $100 \%$ \\
\hline
\end{tabular}

Test of Classic Assumption

\section{Heteroscedasticity}

Heteroscedasticity test aims to test whether in the regression model variance inequality occurs. The heteroscedasticity statistical test results obtained in this study are as follows:

\section{Scatterplot}

\section{Dependent Variable: $y$}

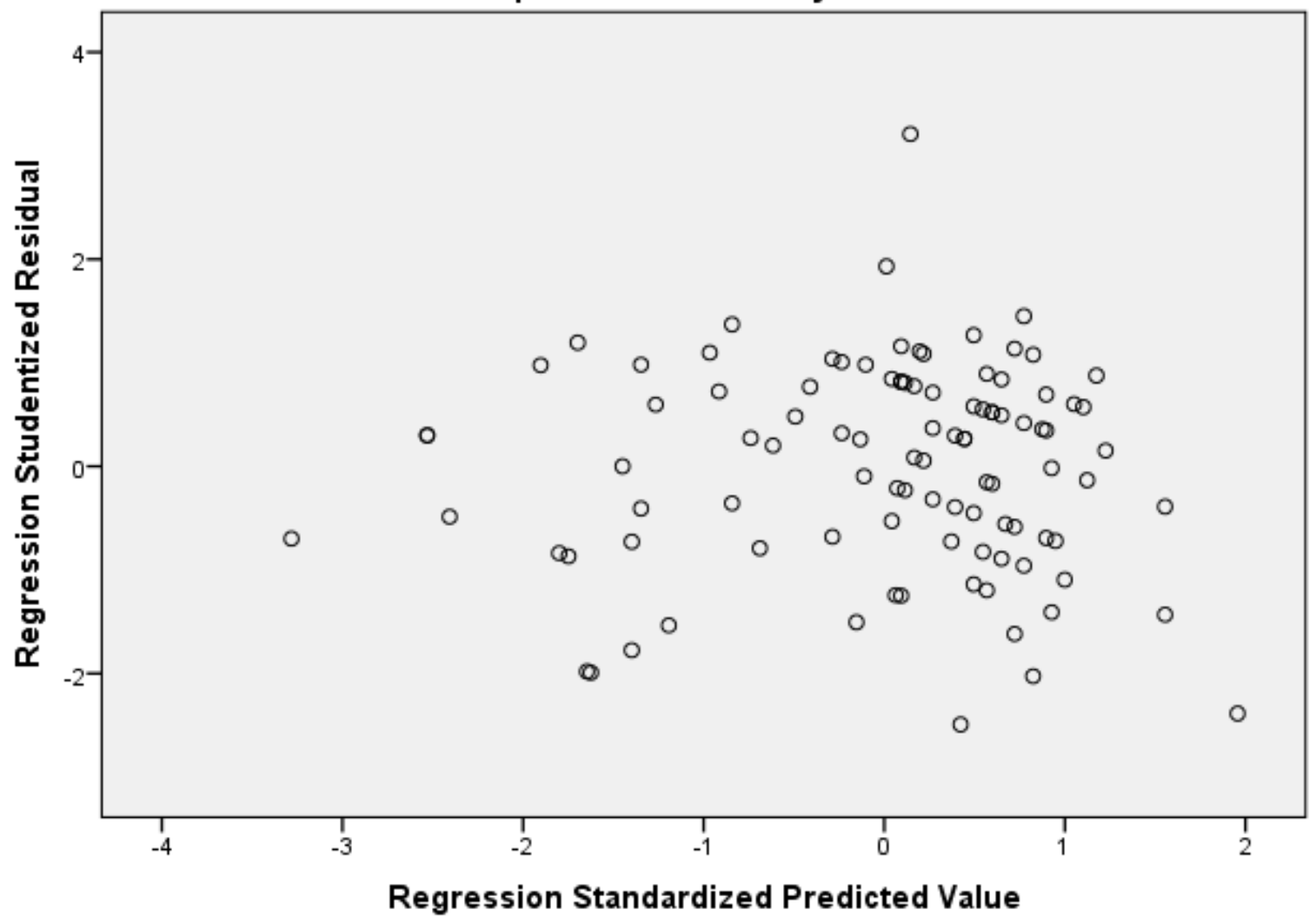

Figure 1. Result of Heteroskedastisitas 
Based on Figure 1 on the results of heteroscedasticity test shows scatterpiot graph shows there is a clear pattern and

\section{Autocorrelation} points that spread above and below the number 0 on the $\mathrm{Y}$ axis. So it can be concluded that there is no heteroscedasticity in the research data.
This test is carried out to test a model of whether the dependent variables of each independent variable influence each other. The autocorrelation test results are as follows:

Table 5. Result of Autokorelasi Test

\begin{tabular}{|c|c|c|c|c|c|}
\hline \multicolumn{6}{|c|}{ Model Summary ${ }^{b}$} \\
\hline Model & $\mathrm{R}$ & R Square & $\begin{array}{l}\text { Adjusted R } \\
\text { Square }\end{array}$ & $\begin{array}{l}\text { Std. Error of the } \\
\text { Estimate }\end{array}$ & Durbin-Watson \\
\hline 1 & $.853^{\mathrm{a}}$ & .728 & .723 & 2.61274 & 1,874 \\
\hline
\end{tabular}

Based on Table 5. regarding the autorrelation test results showed from the test results using the durbin-waston test above, obtained a DW of 1.8874 , then a DW of $1.8874>$ DU 1.715 so there is no correlation problem. So based on Watson's durbin statistical test values in this study there was no autocorrelation.

\section{Multicollinearity}

In this study to test the presence of multicollinearity seen from the VIF (Variance Inflation Factor) or tolerance value. According to Ghozali (2011: 106), that multicollinearity occurs when a VIF value $>10$ or tolerance $<0.10$.

Table 6. Result of Multikolinieritas Test

\begin{tabular}{ccc} 
Variable & VIF & Details \\
\hline E-commerce Implementation $\left(\mathrm{X}_{1}\right)$ & 1,541 & Free of Multicollinearity \\
Competency $\left(\mathrm{X}_{2}\right)$ & 1,541 & Free of Multicollinearity \\
\hline
\end{tabular}

Seen from Table 6 . the results of multicollinearity testing showing VIF values $<10$ all show the same results, namely for the e-commerce variable (X1) and Competency (X2), which is $1.541<10$ meaning that the data is free from multicollinearity symptoms. 


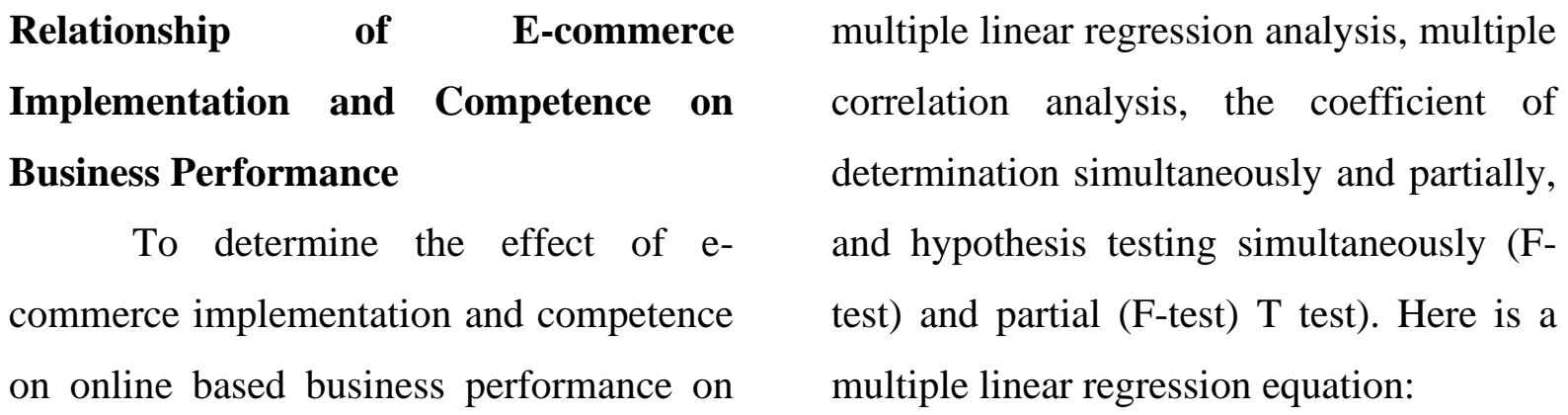
students at Pasundan University, Bandung,

Table 7. Multiple Regression and Correlation

\begin{tabular}{|c|c|c|c|c|c|c|c|c|}
\hline \multirow[t]{2}{*}{ Model } & \multicolumn{2}{|c|}{$\begin{array}{l}\text { Unstandardized } \\
\text { Coefficients }\end{array}$} & \multirow{2}{*}{$\begin{array}{c}\text { Standardized } \\
\text { Coefficients } \\
\text { Beta }\end{array}$} & \multirow[t]{2}{*}{$\mathrm{t}$} & \multirow[t]{2}{*}{ Sig. } & \multicolumn{3}{|c|}{ Correlations } \\
\hline & B & Std. Error & & & & Zero-order & Partial & Part \\
\hline (Constant) & 9.461 & 1.347 & & 7.022 & .000 & & & \\
\hline e-commerce & .230 & .044 & .297 & 5.232 & .000 & .552 & .469 & .277 \\
\hline kompetensi & .501 & .041 & 699 & 12.297 & .000 & .807 & .781 & .651 \\
\hline
\end{tabular}

After processing the data, multiple linear regression equations are obtained:

$$
Y=9,461+0,230 X_{1}+0,501
$$

Where: $\mathrm{Y}=$ Performance, $\mathrm{X} 1=$ Implementation of e-commerce, $\mathrm{X} 2=$ Competence.

\section{Hypothesis Test}

Based on the processing carried out by researchers as shown in table.4.45, it can be seen that the F-value of e-commerce variables and competency together on performance is 129,964 with a significance of 0,000 . Then the Significant $F$ value is $10 \%(\mathrm{a}=0.10)$ and the degree of freedom $(n-3)=97$ is 2.36. Because F-value $(129,964)$ is greater than F-table $(2.36)$, then at a rate of error of $10 \%$ it was decided to reject Ho so that Ha was accepted, "meaning there is a significant influence of ecommerce and competency together on performance".

Table 8. Simultan Hypothesis Test Results (Test F)

\begin{tabular}{|c|c|c|c|c|c|}
\hline \multirow[b]{2}{*}{ Model } & \multicolumn{3}{|c|}{ ANOVA $^{a}$} & \multirow[b]{2}{*}{$\mathrm{F}$} & \multirow[b]{2}{*}{ Sig. } \\
\hline & Sum of Squares & Df & Mean Square & & \\
\hline Regression & 1774.370 & 2 & 887.185 & 129.964 & $.000^{\mathrm{b}}$ \\
\hline Residual & 662.162 & 97 & 6.826 & & \\
\hline Total & 2436.533 & 99 & & & \\
\hline
\end{tabular}

a. Dependent Variable: kinerja

b. Predictors: (Constant), kompetensi, e-commerce 
Based on the above table, it can be proven that the better e-commerce implementation and competence will improve the performance of online business ventures of students at Pasundan University, Bandung.

\section{Partial Hypothesis Testing}

To prove whether e-commerce has a significant effect on performance, a statistical hypothesis test is performed with the following results:

Table 9. Partial Hypothesis Test Results (t Test) E-commerce Variables Coefficients $^{\mathbf{a}}$

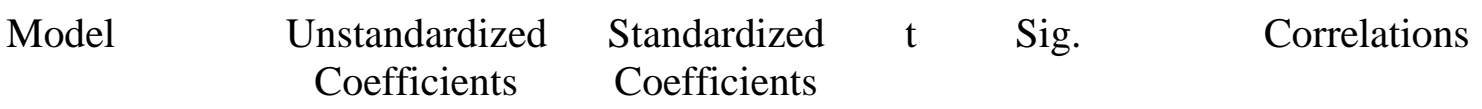

\begin{tabular}{lrrrrrrrr} 
& \multicolumn{1}{c}{ B } & Std. Error & \multicolumn{1}{l}{ Beta } & & Zero-order & Partial & Part \\
\hline (Constant) & 9.461 & 1.347 & & & 7.022 & .000 & & \\
e-commerce & .230 & .044 & .297 & 5.232 & .000 & .552 & .469 & .277 \\
kompetensi & .501 & .041 & .699 & 12.297 & .000 & .807 & .781 & .651 \\
\hline
\end{tabular}

a. Dependent Variable: kinerja

Based on the processing carried out by researchers as shown in Table 9, it can be seen that the t-value of e-commerce variables on performance is 5,232 with a significant value of 0,000 . Then the value of t-table at the Significant level of 10\% $(\mathrm{a}=$ $0.10)$ and the degree of freedom $(n-3)=97$ is 1,290 . Because $t$-value $(5,232)$ is greater than $\mathrm{t}$-table $(1,290)$, then at a rate of error of $10 \%$ it was decided to reject Ho so that $\mathrm{Ha}$ was accepted, "meaning there is a significant effect of e-commerce on performance". The results of this study prove empirically that the better implementation of e-commerce will improve the performance of online business ventures of students at Pasundan University, Bandung.

\section{Regression Coefficient Analysis and Determination Coefficient}

Based on the calculations in Table 10. shows that e-commerce and competence together have a significant effect on business performance, the coefficient of determination obtained from the results of data processing is presented as follows:

\section{Table 10. Simultaneous Correlation Coefficient and Determination Results Model Summary

\begin{tabular}{lrrrr} 
Model & R & R Square & $\begin{array}{c}\text { Adjusted R } \\
\text { Square }\end{array}$ & $\begin{array}{l}\text { Std. Error of } \\
\text { the Estimate }\end{array}$ \\
\hline 1 & $.853^{\mathrm{a}}$ & .728 & .723 & 2.61274 \\
\hline
\end{tabular} \\ a. Predictors: (Constant), kompetensi, e-commerce}


In Table 10 above it can be seen that the correlation coefficient between ecommerce and competency together on performance is 0.853 meaning the relationship between e-commerce and competence on performance is strong while the magnitude of influence is equal to 0.728 . It can be seen that the influence of ecommerce (X1) and competence (X2) on the performance $(\mathrm{Y})$ of online-based businesses on students at Pasundan University is large. To determine the effect of variables partially, it can be calculated:

1. The influence of e-commerce (X1) on Performance $(\mathrm{Y}), 0.297 \times 0.552=$ 0.164

2. The effect of competence (X2) on performance $(\mathrm{Y}), 0.699 \times 0.807=$ 0.564

Based on these calculations shows that the influence of e-commerce (X1) on business performance (Y) of 0.164 smaller effect than competence (X2) on business performance (Y) of 0.564 and the rest is influenced by other variables not researched by the author.

\section{DISCUSSION}

The results of the correlation analysis is a coefficient value of 0.853 which belongs to a strong relationship. The correlation that occurs is a positive correlation. This shows that there is a strong relationship between e-commerce (X1) and competence $(\mathrm{X} 2)$ on business performance (Y). The calculation results also showed that the effect of e-commerce implementation and competence was 0.728 . Although the results of the partial influence test show that competence has a dominant influence on the success of businesses run by students with an effect of 0.564 while e-commerce implementation is 0.164 , competency in using the internet includes the ability to innovate is an important aspect in the success of the business being run by students (Fritsch \& Slavtchev, 2007) The results of this study are not different from Yulimar (2014). Likewise Farida (2017) regarding factors that influence e-commerce adoption and its effect on the performance of SMEs where the results show an effect of 0.68 .

The effect of competence is greater than the implementation of e-commerse on student business performance. The results of this study were supported by Schlenker and Crocker (2003) and Victoria (2014). Considering that competence is related to the ability to use the internet in running a business, it can be seen that businesses run by students today are still less successful due to this. Student competencies are still lacking. This fact shows that the reality of ecommerce adoption by SME entrepreneurs in developing countries is still at an early stage, namely for marketing, purchasing, 
and procurement activities (Rahayu \& Day, 2017).

\section{CONCLUSIONS}

The results of the study proves that the implementation of e-commerce and competence influences the business success of Pasundan University students. Although the influence of competence is greater than the implementation of e-commerce, business competence that should be possessed by students is closely related to the ability to use e-commerce. This shows that all hypotheses are accepted and the general reality that the internet is increasingly important for business is not rejected.

Most of the businesses run by students are still on the SME scale so that this behavior is not in conflict with the results of other studies, support from universities and government is needed so that this problem can be resolved and students can contribute to local economic growth specifically, and nationally in general. The government can provide support through technology and the environment, while universities can provide support through the curriculum.

\section{REFERENCES}

Adamek, P. (2007). Infrastructure for Innovations and Internationalisation of SME Activity, in Entrepreneurship Environment and Policies: Exploiting the Science and Technology Base in the Region of Halle. Discussion Paper, OECD, Paris.

Chong, S. and Pervan, G. (2009). Factors Infuencing the Extent of Deployment of Electronic Commerce for Smalland Medium-Sized Enterprises, IGI Global.

Fritsch, M. and V. Slavtchev (2007), Universities and Innovation in Space, Industry and Innovation. 14 (2), , pp. 201-218.

Ghozali, I. (2011). Aplikasi Analisis Multivariat Dengan Program SPSS. Semarang, Badan Penerbit Universitas Diponegoro

Han L., and Jin, Y. (2009). A Review of Technology Acceptance Model in the E-commerce Environment, International Conference on Management of e-Commerce and $e$ Government, 64, 28-31.

Kareem. (2014). Electronic Commerce and Business Performance: an empirical Investigation of Business Organization in Nigeria. International Journal of Academic Research in Business and Social Sciences, .4(8) 
Kapurubandara, M. and Lawson, R. (2008). Avaibility of E-commerce Support for SMEs in Developing Countries, The International Journal on Advances in ICT for Emerging Region, 01,pp. 3-11. Lesmono, I. D. (2015). The influence of $E$ Commerce on development of SMEs: Technology Acceptance Model Usage. Manajemen Kewirausahaan Journal, 3 (1), pp 31-45

Maryeni, Y.Y., Govindaraju, R., Prihartono, B., \& Sudirman, I. (2014), Ecommerce Adoption By Indonesian SMEs, Australian Journal of Basic and Applied Sciences, 8 (14), pp 45-49

Mendo, F.A. dan Fitzgerald, G. (2005) : A Multidimensional framework for SME e-business progression, Journal of Enterprise Information Management, 18 , No. 6, 678-696.

Farida, N. (2017). Model of Relationship Marketing and E-Commerce in Improving Marketing Performance of Batik SMEs, Jurnal Dinamika Manajemen. 8 (01).

Ratnamiasih, I \& Indra Setia, B. (2016), Internal and External Factors that Influence Student Entrepreneurship Intention on Private Universities in Bandung Widyatama International Seminar on Sustainability, 8 (1), Pp 394-400

Rahayu, R \& Day, J. (2015). Determinant factors of E-commerce adoption by
SME's in developing Country: evidence from Indonesia. Procedia, Social and Behavioral Sciences, 19 (5), 3 July 2015, pp 142-150

Rahayu, R \& Day, J. (2017). E-commerce adoption by SME's in Developing Countries: evidence, Eurasian Business Review, 7, pp. 25-41

Sekaran, U., (1992) : Research Methods for Business : A Skill Building approach, Second Edition, John Wiley \& Sons Inc., USA

Schlenker, L. and Crocker, N. (2003). Building an e-business scenario for small business: The IBM SME Gateway project, Qualitative Market Research, 6, No. 1, 7.

Sethela, J. (2014). Determining the Importa nce of Competency an d Person-Job Fit for the Job Performance of Service SMEs Employees in Malaysia, journal Asian Social Science. 9 (10).

Victoria, A. (2014). E-Commerce Adoption Among Small And Micro Enterprises In Nairobi, A Research Project Presented In Partial Fulfillment Of The Requirements For The Award Of Master Of Business Administration(Mba), School Of Business Of The University Of Nairobi, October 2014, Pp 1-41 
JAFTA - Vol 3 Nomor 1, Maret (2021)

Yulimar, V..A. (2014). Analysis of

Influence E-commerce Adoption on Business Performance SME's, Jurnal Teknologi dan informasi, 2 (2), pp 28-40 